\title{
Honeywell
}

\section{Agile Machining and Inspection Non-Nuclear Report (NNR) Project}

Federal Manufacturing \& Technologies

L. J. Lazarus

KCP-613-8552

Published February 2009

Final Report

Approved for public release; distribution is unlimited.

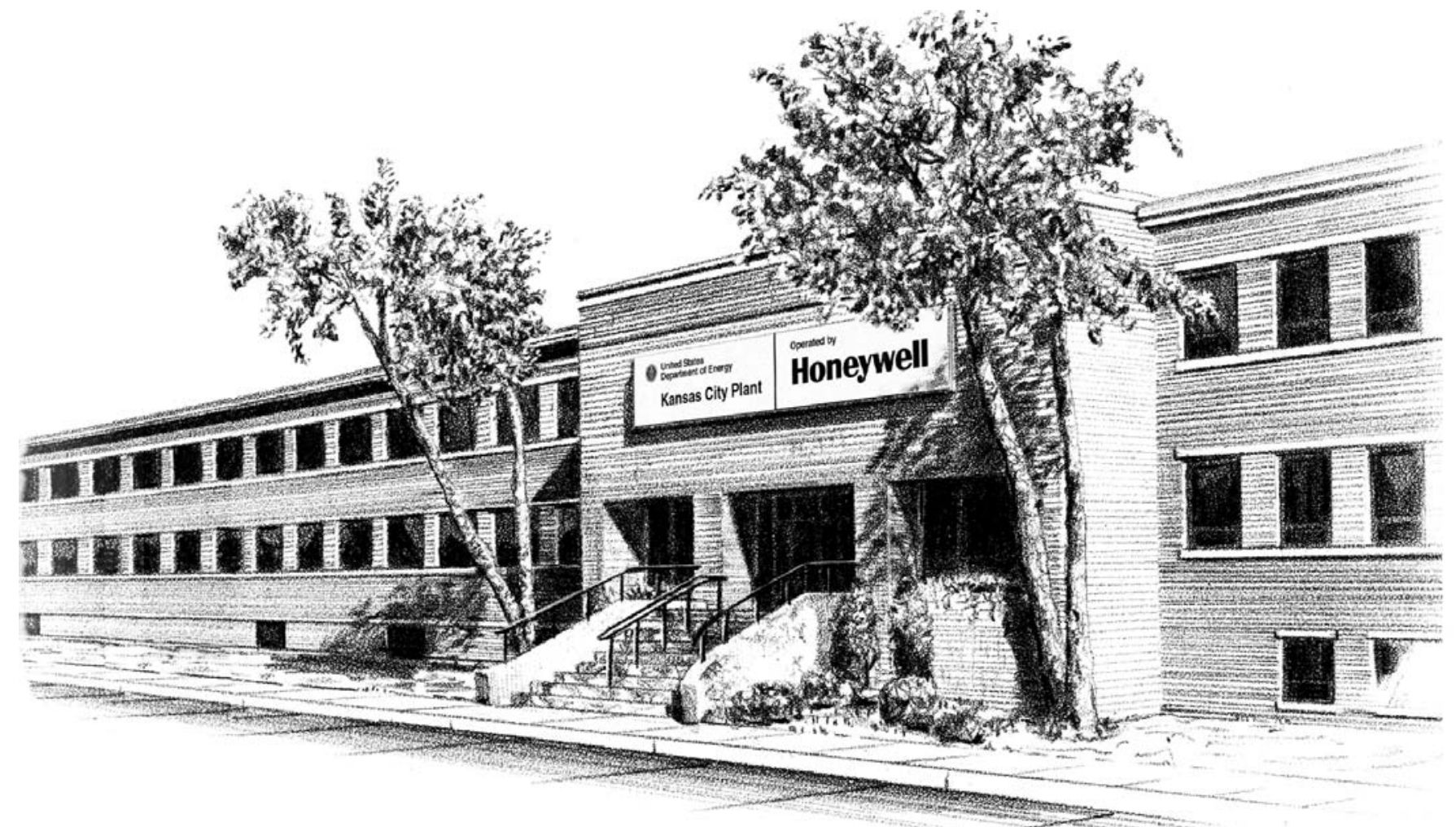




\section{DISCLAIMER}

This report was prepared as an account of work sponsored by an agency of the United States Government. Neither the United States Government nor any agency thereof, nor any of their employees, makes any warranty, express or implied, or assumes any legal liability or responsibility for the accuracy, completeness, or usefulness of any information, apparatus, product, or process disclosed, or represents that its use would not infringe privately owned rights. Reference herein to any specific commercial product, process or service by trade names, trademark, manufacturer, or otherwise, does not necessarily constitute or imply its endorsement, recommendation or favoring by the United States Government or any agency thereof. The views and opinions of authors expressed herein do not necessarily state or reflect those of the United States Government or any agency thereof.

All data prepared, analyzed and presented has been developed in a specific context of work and was prepared for internal evaluation and use pursuant to that work authorized under the reference contract. Reference herein to any specific commercial product, process or service by trade name, trademark, manufacturer, or otherwise, does not necessarily constitute or imply its endorsement, recommendation or favoring by the United States Government, any agency thereof or Honeywell Federal Manufacturing \& Technologies, LLC.

Printed in the United States of America.

This report has been reproduced from the best available copy.

Available to DOE and DOE contractors from the Office of Scientific and Technical Information, P.O. Box 62, Oak Ridge, Tennessee 37831; prices available from (865) 576-8401, FTS 626-8401.

Available to the public from the National Technical Information Service, U.S. Department of Commerce, 5285 Port Royal, Rd., Springfield, Virginia 22161, (703) 487-4650.

A prime contractor with the United States Department of Energy under Contract Number DE-AC04-O1AL66850

\author{
Honeywell Federal Manufacturing \& Technologies \\ P.O. Box 419159 \\ Kansas City, Missouri, 64141-6159
}




\section{Honeywell}

KCP-613-8552

Distribution Category UC-42

Approved for public release; distribution is unlimited.

Agile Machining and Inspection Non-Nuclear Report (NNR) Project

L.J. Lazarus

Published February 2009

Final Report 



\section{Contents}

Section Page

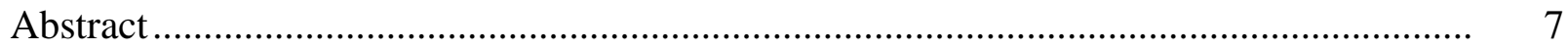

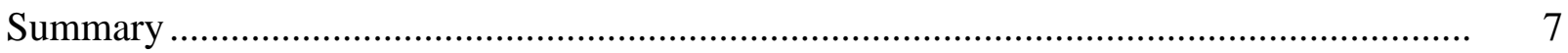

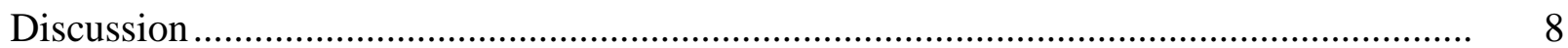

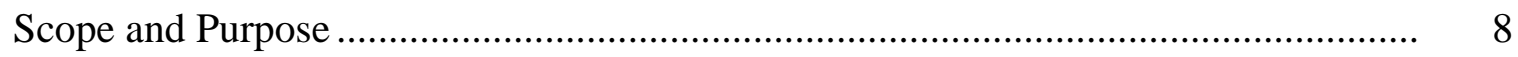

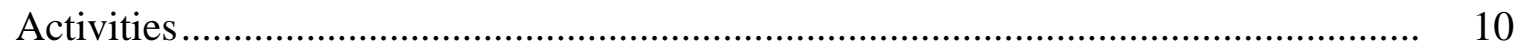

703024 - Machine Simulation Implementation........................................ 10

703025 - Rapid Response Small Machining ............................................. 11

703027 - Open Architecture Controls and Machine

Tool Upgrades \& Machine Tool Modernization - 01902701............................ 18

703040 - DNC/CRONOS Deployment ...................................................... 22

703041 - OMGEC for OA/American Lathes .................................................. 25

703042 - 3D-Micro Scale Implementation................................................ 25

706685 - CMM Technology ............................................................. 26

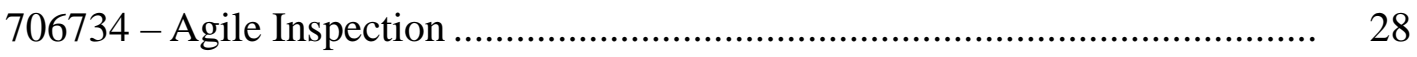

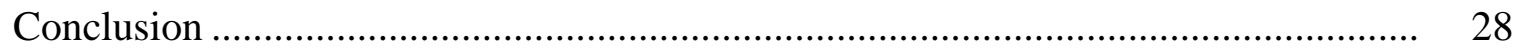




\section{Illustrations}

Figure Page

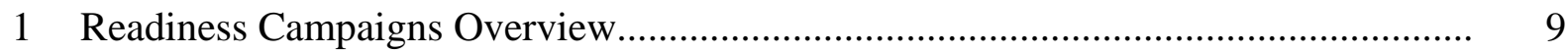

2 Agile Machining \& Inspection

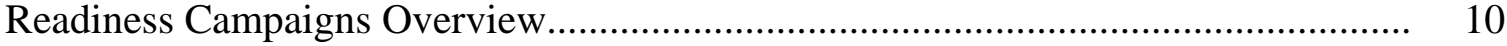

3 Vericut Models of Machine Tools ................................................................... 11

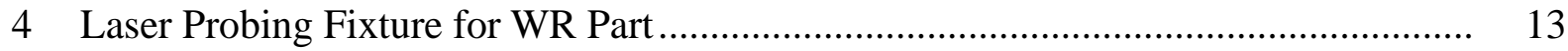

5 Pallet System Installed on a

Monarch VMC 75B Machining Center ............................................................... 14

6 Virtual Optical Comparator for Small Part Inspection ......................................... 15

$7 \quad$ Typical Installation of a Chiller on a Lathe ....................................................... 15

8 Screen Shot of NC Website......................................................................... 16

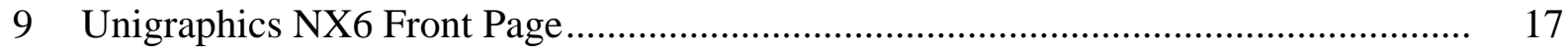

10 Readiness Campaigns Slide Presentation ..................................................... 20

11 Article from "Connections"

K\&T Machining Center w/OA Control in Background........................................... 22

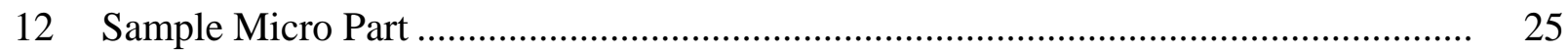

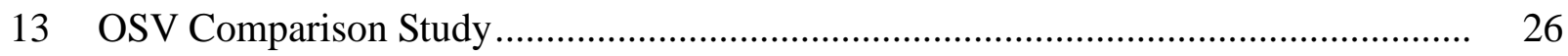

14 Automatically Generated Product

Score Card and Inspection Summaries ............................................................ 27

15 Classification Markings Added

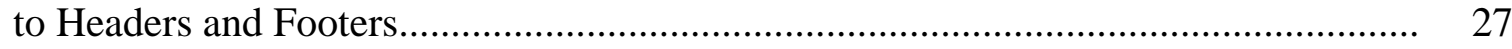

\section{Tables}

Number Page

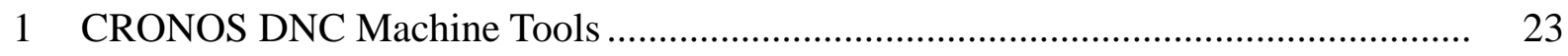




\begin{abstract}
This report is a high level summary of the eight major projects funded by the Agile Machining and Inspection Non-Nuclear Readiness (NNR) project (FY06.0422.3.04.R1). The largest project of the group is the Rapid Response project in which the six major sub categories are summarized. This project focused on the operations of the machining departments that will comprise Special Applications Machining (SAM) in the Kansas City Responsive Infrastructure Manufacturing \& Sourcing (KCRIMS) project. This project was aimed at upgrading older machine tools, developing new inspection tools, eliminating Classified Removable Electronic Media (CREM) in the handling of classified Numerical Control (NC) programs by installing the CRONOS network, and developing methods to automatically load Coordinated-Measuring Machine (CMM) inspection data into bomb books and product score cards. Finally, the project personnel leaned operations of some of the machine tool cells, and now have the model to continue this activity.
\end{abstract}

\title{
Summary
}

This report is a high level summary of the eight major projects funded by the Agile Machining and Inspection, NNR project (FY06.0422.3.04.R1). The project was split up into major subprojects that addressed:

- 703024 - Machine Simulation Implementations

- 703025 - Rapid Response

Non-Contact Laser Probing

Pallet Systems

Virtual Optical Comparator

MWF Temperature Control

NC Process Improvements

Work Cell Capabilities

- 703027 - Open Architecture Controls

- 703040 - DNC/CRONOS Implementation

- 703041 - OMGEC for OA American Lathes

- 703042 - 3-D Micro Scale Implementation

- 706685 - CMM Technology

- 706734 - Agile Inspection

The largest project in the group, 703025, was broken up into six major area and summaries are included on these projects.

All address the transition of the machining department to the KCRIMS SAM and how to implement lean practices in daily operations of the machining cells.

Emphasis was placed in implementing and deploying new technologies to reduce cycle time and improve product flow within the department. Individual reports on the major projects outline cost savings achieved and productivity events that were submitted by the project 
leads. In addition, many older machine tools were upgraded with new Open Architecture (OA) Controls, new resolvers and servo drives that allowed probing to be installed on the Computer Numerical Controlled (CNC) lathes. These older machines are now more reliable, repeatable and accurate.

\section{Discussion}

\section{Scope and Purpose}

The National Nuclear Security Administration (NNSA) decided that commercial quality would be acceptable for unclassified War Reserve (WR) product. NNSA and Federal Manufacturing \& Technologies (FM\&T) senior plant management agreed that the Kansas City Plant (KCP) should be downsized and unclassified WR components could be fabricated by outside vendors. Also proposed was a new, smaller facility with a machining area that combined precision machining, the model shop and the tool room into a new department SAM. This combined department was $40 \%$ the size of the original departments with only $40 \%$ of the machine tools. These decisions affected the business case for the Agile Machining and Inspection NNR project. The original business case was aimed at replacing older machine tools in the precision machining department with more productive machine tools to meet the work load requirements. No additional machine tools would be purchased with NNR funding and the project had to be redesigned.

The author made a presentation on March 7, 2006 to the Readiness Campaigns, and Subprogram manager for Advanced Design and Production Technologies (ADAPT) and NNR Programs, on the revised Agile Machining \& Inspection project and explained how this project was being changed to accommodate this new operating philosophy (the Agile project became agile and retailored itself). 


\section{Readiness Campaigns \\ Kansas City Plant ADAPT / NNR Overviews}

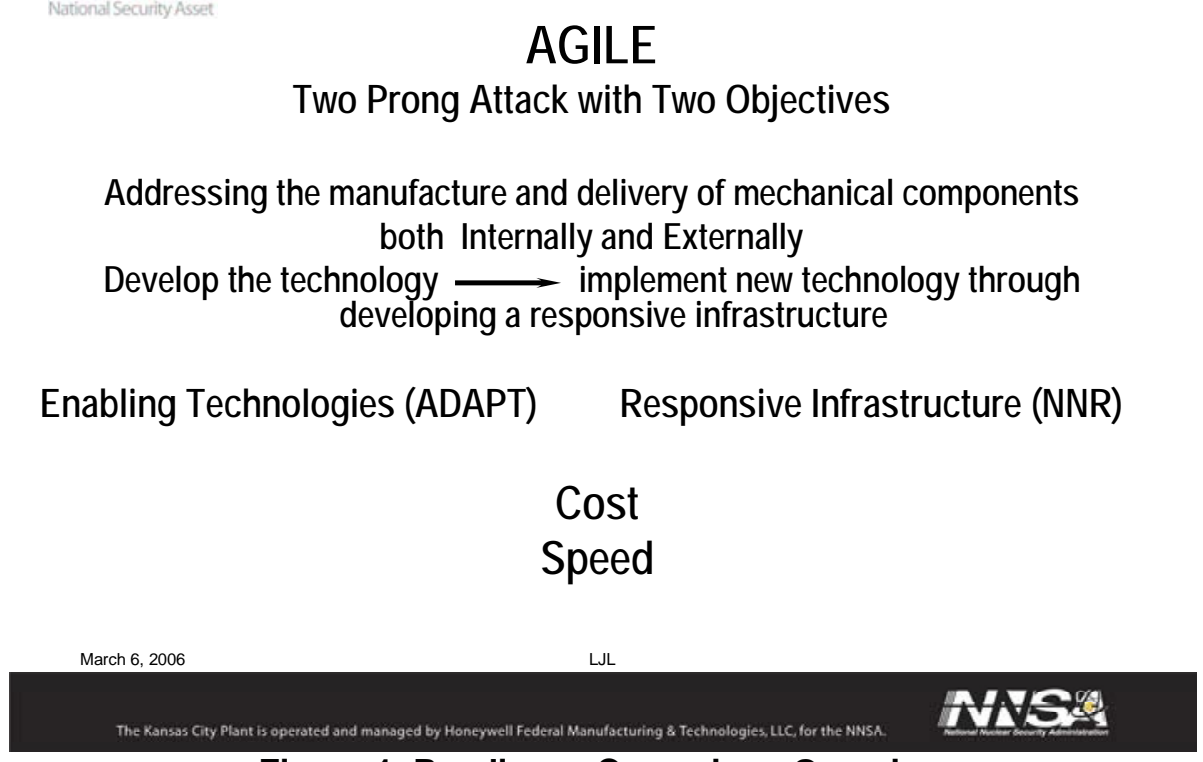

Figure 1. Readiness Campaigns Overview

Emphasis was placed on leaning out processes, rebalancing equipment loading, applying new technologies, and finding ways to operate more responsively and quicker. The new projects and their goals funded by this project were presented. Since 2006, additional changes have been made to meet the goal of making SAM more effective and contributing to the overall efficiency of KCP. All project leads took into consideration KCP's new operating philosophy and future configuration.

The restated scope and purpose of the Agile Machining and Inspection project was to institute lean practices, apply new technologies so that KCP could respond to product change in quicker fashions and remove the road blocks associated with change.

At that presentation the following NNR projects were currently active and in-work (see Figure 2). 


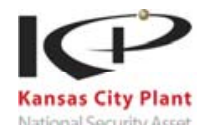

National Security Asset
Readiness Campaigns

ADAPT I NNR Overviews

Agile Machining \& Inspection

\section{NNR (FY06 \$1.958M)}

FY06.0422.03

- Machine Simulation Imp (\$50k)

- Rapid Response (\$1.59m)

- Open Architecture Controls (\$200K)

- DNC Upgrades (\$150k) Fines 703029,

New FY07 Projects

Pro NC (\$100K)

Agile Inspection (\$400K)

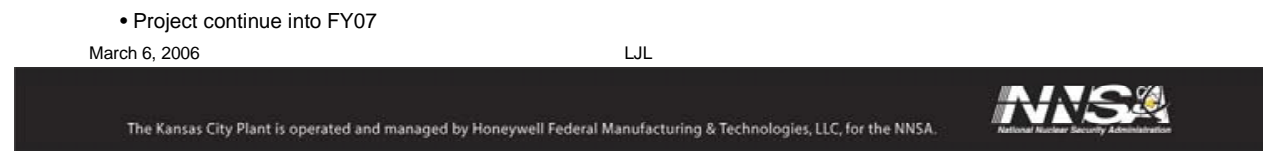

Figure 2. Agile Machining \& Inspection Readiness Campaigns Overview

Since that time some of the projects have been completed, others redefined and others have been opened.

\section{Activities}

\section{4 - Machine Simulation Implementation - (L2 Milestone)}

The team is responsible for the creation, testing and release for use of machine tool simulation models utilizing VERICUT software. Virtual simulation of machine tool programs saves time and money by detecting program errors and collisions before the program is run on the machine tool. The simulations also have been used to support development of machining processes, especially when determining clearances between cutting tools, part and fixturing.

This is the final year of this project. All machines tools that will be moving to the new facility are now supported. Development for the process of loading, machining and unloading for the component reentry body was simulated. This effort resulted in time savings that allowed the project to be completed early and under budget.

The following machines have been developed and released in FY08:

Pnuemo T-bed lathe w/MDSI control

American lathe w/ MDSI control

Monarch VMC 175 w/Fanuc control

Levin lathe w/ MDSI control 
Moore T-bed lathe w/MDSI control

Hurco 3 axis vertical mill w/ Hurco control

Hurco 4 axis vertical mill w/ Hurco control

Toyoda 5 axis mill w/ Fanuc control

Mori Seiki 4 axis mill w/ Fanuc control

Mori Seiki mill/turn w/ Mitsubishi control

These machine tools were modeled in FY06 and FY07:

FMS K\&T Orion/ GL8000; 4 axis horizontal mill

Hardinge Chucker/ MDSI; 2 axis lathe

Monarch VMC75/ Fanuc; 4 axis vertical mill

American Lathe/ MDSI; 2 axis lathe

Mori Seiki/Mori Seiki; 4 axis lathe

Hermle 5 axis Mill/ Heidenhien; 5 axis vertical mill

K\&T Moduline/ GL8000; 5 axis horizontal mill

K\&T Moduline w/ High Speed Head/ Gemini; 5 axis horizontal mill

Monarch Cortland 3 axis vertical mill

Dixi 5 axis horizontal mill

Mitsui Seiki 5 axis horizontal mill (with probing)

Hermle 5 axis horizontal mill (with probing)

Gildemeister mill/turn machining center

Mori Seiki 3 axis vertical mill (with probing)

Sundstrand OmniMill 5 axis tilt head mill

Hardinge TS51SP Lathe

Hardinge Quest 65SP Lathe

A final report with links to the NC web page is being generated.

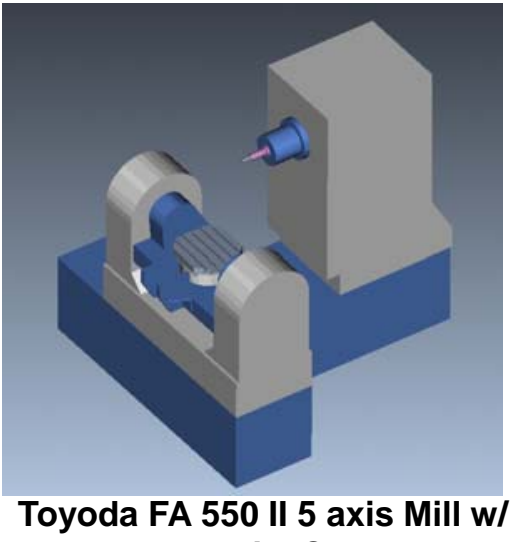

Fanuc 16iM Control

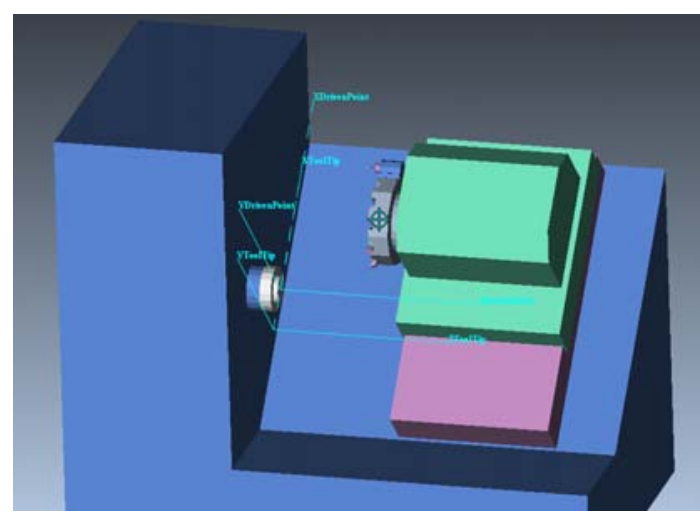

Hardinge T42SP Lathe w/ Fanuc 18T Control

Figure 3. Vericut Models of Machine Tools

\section{5 - Rapid Response Small Machining}

At the inception of the Agile Machining and Inspection Project, this particular project was aimed at obtaining new machine tools to upgrade and round out KCP machining capability. 
With NNSA acceptance of commercial quality for nuclear components, outsourcing unclassified machining, downsizing the machining departments and KCRIMS, the scope of this project changed. This project became the vehicle to lean out machining operations, look at implementing proven technologies to improve KCP's process, and make the machining departments more agile.

The sub-activities were broken up into a number of different activities that included:

- Virtual Optical Comparator

- Stereolit Gauging

- Laser Mapping

- Agile Machining Process Standardization

- Small Swiss-Style Mill Turn

- $\quad$ NC Tape Generation Streamlining

- Pallet Study in Preparation for SAM

- First Piece Inspection CMM $\backslash$ Embedded Engineering

- Conversational Programming

- Heat Exchanger Kellenberger Hydraulic System

- Chiller - Metalworking Fluids on Precision Lathes

- Implementing Lean in SAM

- High Speed Machining

- Reprocess the component housing from Department A to Department B

A formal report, KCP-613-8533, "Rapid Response Small Machining” has been completed on this project that details the activities that were funded. Below are the highlights for 2008 on the individual sub-projects.

\section{Non-Contact Laser Probing - Subproject}

A method of using non-contact laser probing for part profile measuring has been implemented. The Los Alamos National Laboratory (LANL)/FM\&T team has completed a full Engineering Evaluation of the measuring system, and the Design Agency (LANL) has fully approved the system with release of a QER for WR acceptance of the syntactic foam product.

The system utilizes standard technologies with novel methods that map a comparative measuring standard to the gage (laser measuring system). The gage provides a near zero measuring impedance to the part to avoid damage, and automates the process in a way that eliminates operator variability and reduced inspection time. The gage will replace a certified CMM acceptance method for profile check, and was expanded to measure other part geometries to eliminate some hard gages. The CMM and gage acceptance methods will provide a backup role. The gage can be used by production personnel for first piece and in process gauging with a quick turn around. 


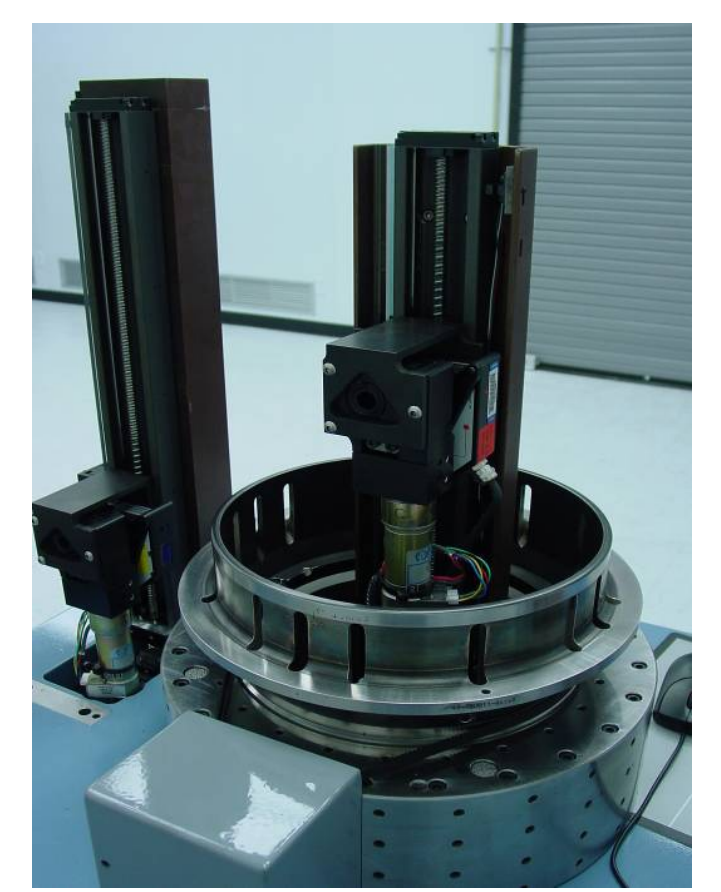

Figure 4. Laser Probing Fixture for WR Part

A formal report, KCP-613-8525, “Non-Contact Gauging with a Laser Probe” has been submitted that outlines the acceptance of this technique by the design agencies to inspect WR components.

\section{Pallet Systems -Subproject - (L2 Milestone)}

Mounting fixtures on the pallet system will allow quick switch out of machining setups in multi-shift operations and allow multiple job classes to use the same machine tool. In the SAM department, both production jobs are run multiple times per year, where work piece material is mounted on production fixtures and development jobs which are small quantities run once in open set-ups.

A study was conducted on System 3R's Delphin Pallet System to test load repeatability for the pallets. A critical question for the use of pallet systems is how well the pallet repeats its position from load to load. The operator and the engineer must be confident in the loading repeatability of the pallet for the system to function as intended.

The test was run on Department B's Hermle, by using the probe to touch specified positions between loads and comparing how close the pallet came to locating in the same position as the previous load. These tests proved the repeatability of the system in the new condition without high side loads.

A production fixture was mounted on a pallet system mounted in a production Cortland VMC-75B Machining Center. Approximately 90 parts were run during the major roughing operation. After every fourth part the pallet system was released and reset. KCP found the system repeated within 0.0003 during the whole run. This was equivalent to normal variation encountered when the fixture was bolted to the table. The setup is shown in Figure 5. 

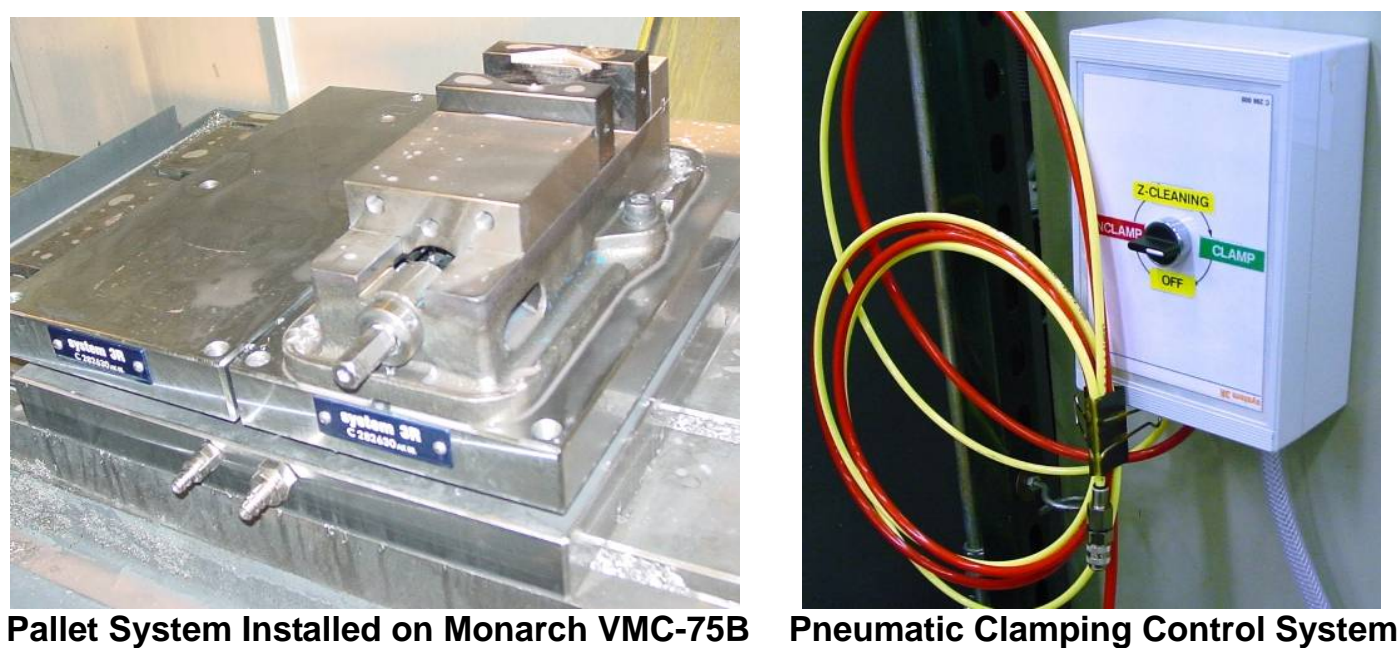

Pallet System Installed on Monarch VMC-75B

Pneumatic Clamping Control System

Figure 5. Pallet System Installed on a Monarch VMC 75B Machining Center

After these tests, eleven base plates were ordered with multiple top plates and hardware. The four section base allows two, two-section top plates to be mounted on the same machine tool. The platen systems will be installed on six Cortland Machining Centers, a Jones \& Shipley Grinder, and four Hermles, (2 in Department G and 2 in Department B). One unit is currently installed on a VMV-75B in Department B.

\section{Virtual Optical Comparator - Subproject}

The Virtual Optical Comparator, (VOC), was conceived as a result of the limitations of conventional optical comparators and vision systems. It was funded by NNR Project 703025, Rapid Response Small Machining. Piece part designs for mechanisms have started to include precision features on the face of parts that must be viewed using a reflected image rather than a profile shadow. The VOC concept uses a computer-generated overlay and a digital camera to measure features on a video screen. The advantage of this system is superior edge detection compared to traditional systems. No vinyl charts are procured or inspected. The part size and expensive fixtures are no longer a concern because of the range of the X-Y table. Product redesigns require only changes to the CAD image; new vinyl charts are not required. The inspection process is more ergonomic by allowing the operator to view the part sitting at a desk rather than standing over a 30 inch screen. The procurement cost for the VOC will be less than a traditional comparator with a much smaller footprint and less maintenance and energy requirements. 


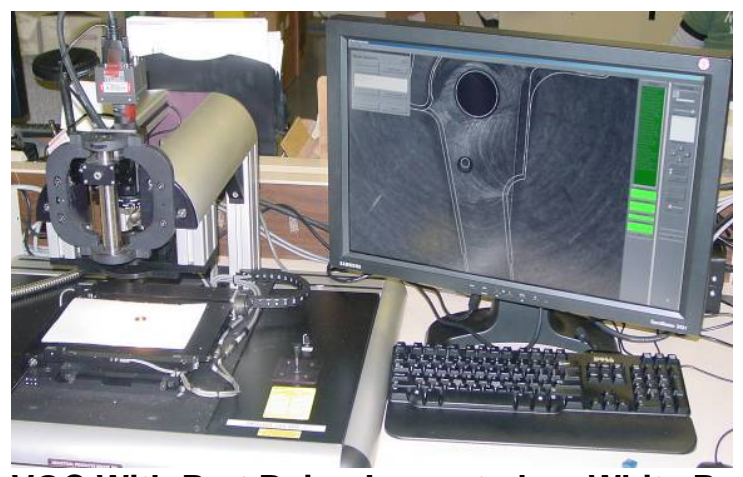

VOC With Part Being Inspected on White Paper Video Image of Part With Overlaid Tolerance

Figure 6. Virtual Optical Comparator for Small Part Inspection

A formal report has been generated, KCP-613-8517, “Virtual Optical Comparator,” which details the activities and accomplishments of this project.

\section{Metal Working Fluid (MWF) Temperature Control - Subproject}

The MWF absorbs the heat generated in the machining process. During the normal shift it is not unusual to have the MWF increase in temperature by $25^{\circ} \mathrm{F}$. When one is trying to maintain tolerances within 0.0002 on a contour, this becomes a factor in maintaining final machined tolerances. The first attempt to control MWF was to install a fluid to air heat exchanger in the return line to the fluid sump on the Kellenberger cylindrical grinders. This lowers the temperature change during the shift to less than $10^{\circ} \mathrm{F}$. The second approach used a chiller to control the MWF sump temperature. This increased the cost for maintaining the temperature significantly, but it performed at a much higher level. For three T-Bed lathes (precision turning machines), chillers have been purchased and installed. In addition, chillers have been added to one of the American lathes. KCP can now maintain the MWF temperature within $3^{\circ} \mathrm{F}$ easily, and better than $2^{\circ} \mathrm{F}$ when making light cuts using a 50-50 mix of oil-based MWFs.
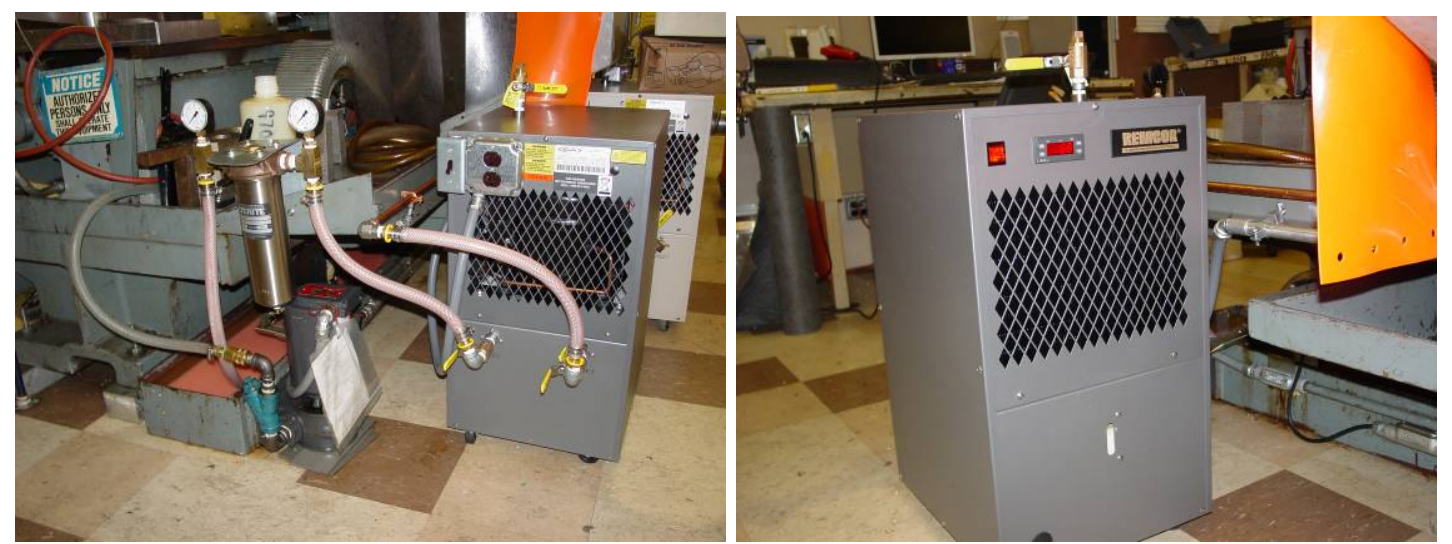

Figure 7. Typical Installation of a Chiller on a Lathe 


\section{NC Process Improvements - Subproject}

The intent of this subproject is to analyze the business practices of the NC programming department, identify, and implement opportunities for improvement. Some businesses practices are inefficient and can cause lengthy turnaround times for program requests as well as being costly on machine prove in time. There are seven $\mathrm{NC}$ analysts who maintain approximately 51 different post processors, and that support approximately 70 machine tools.

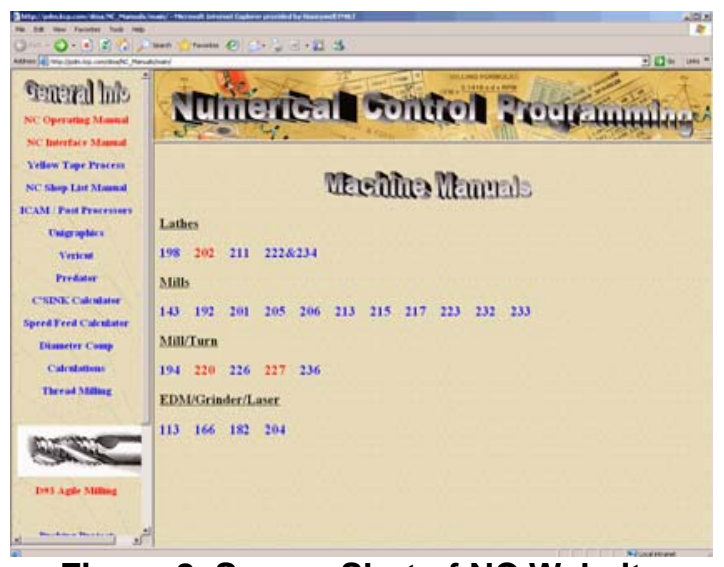

Figure 8. Screen Shot of NC Website

With the wide variety of tools and applications used plant-wide, it is difficult for individual analysts to be proficient in all applications of every process. NC analysts specialized in a certain area which limits flexibility. A major goal of this subproject was to identify methods of capturing and retaining machine or process specific knowledge so that it could be easily communicated to all analysts. This led to the creation of the NC Online Manuals website. This project allowed KCP to build up and expand this website. This easily accessible database of knowledge is also available to process engineers, machinist and model makers.

Unigraphics is the Computer-Aided Manufacturing (CAM) software used at KCP. Since all programmers are familiar with differing functions of the software, KCP has implemented a Unigraphics users group which meets regularly and allows personnel to present and share challenges encountered and solutions to issues department wide. This gives an open forum to proactively gain knowledge and be aware of potential pitfalls instead of trying to reactivity find solutions during a crisis. 


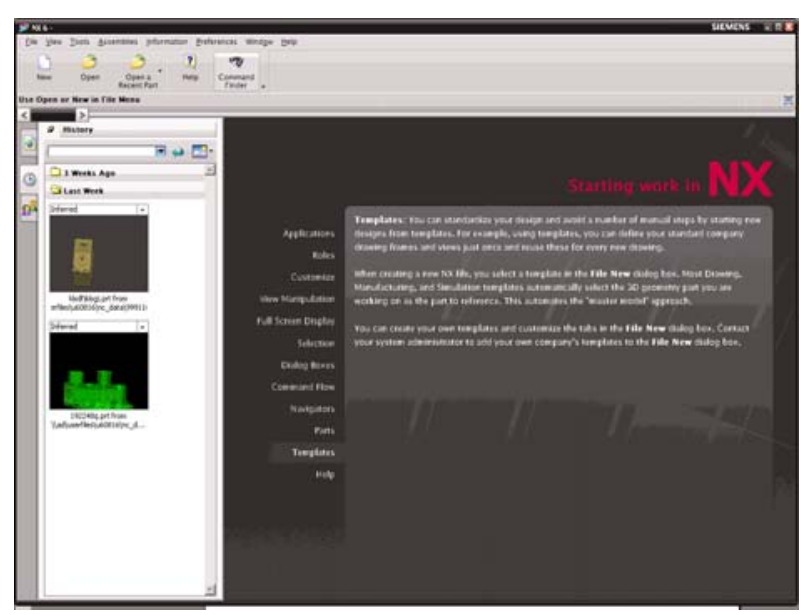

Figure 9. Unigraphics NX6 Front Page

Minor procedural changes have increased efficiency but they are difficult to quantify. Increased collaboration with the process engineering departments and shop floor personnel are vital to the success of the NC program. A direct communication step with customers was added to internal procedures. This step can eliminate hours of unnecessary programming time by verifying the intent of the programming, and eliminating or controlling any manufacturing variables.

Custom part templates have also greatly increased efficiency. By using templates, it increases the uniformity of the group's programming methods. This makes it exponentially easier for analysts to go from one program to another and be able to readily trouble shoot an issue, regardless of whom the original author was.

The NC software is upgraded regularly. All changes must be carefully scrutinized to ensure that they meet the mission requirements and will generate reliable output from work done in prior editions of the software. This is done to ensure KCP's ability to regenerate and produce parts that were made long ago, which KCP must maintain production capability for the life of the system. New revisions of software also lead to improvements in usability and function that simplify the work and dramatically reduce turnaround time. As a result of this subproject, KCP will soon be completely upgraded to Unigraphics NX6.

\section{Work Cell Capabilities - Subproject}

A number of small projects have been undertaken to improve the capabilities of the work cells as they will be setup in the new facility. The projects listed give an idea of the scope of activities. They include standard setup carts for each work cell. This makes sure the right items necessary to setup a job within the cell are within the reach of the machinist or tool maker setting up the job. This concept was proven out as part of the Hermle Milling Cell. KCP has increased the compliment of live tooling for the Mori Seiki Mill Turn cell. The tool makers are using more live tooling in producing parts and avoiding making extra set-ups. Small center sets have been obtained for the Gildemeister Mill Turn Cell and the Star Cell so that machined component concentricity between different diameters can be easily checked. Since these machines have multiple spindles and the fabricated part get passed from one 
spindle to another so that both ends of the part can be machined. This concentricity check must be made to assure compliance to drawing requirements before a lot of parts are sent to inspection. This improves cell performance and reduces scrap. A Machinist can easily tell if a tool is forming a small burr that is effecting the clamping in the tail stock spindle. A small project was completed to redesign the harperizing and vibratory deburr area for better work flow. This requires the purchase of a combination storage unit to replace three different units. A standard part was developed to check the relationships of the Gildemeister spindles. This part also can be used for qualification of the machine tool after the machine tool is moved as part of KCRIMS. In addition, cross training has started of the machinists in Department B and tool makers in the model shop and tool room on the common equipment that includes the White Sundstrand, Hermles, and Charmiles EDM's.

\section{7 - Open Architecture Controls and Machine Tool Upgrades} \& Machine Tool Modernization - 01902701

This project was undertaken to upgrade older machine tools that used mini-computers and proprietary computer controls from General Automation, Allen Bradley (various models), G\&L (Model 8000), Bendix (System 5, 5C, 5CM), Fanuc T-3 and Bostomatic. These older computer systems, some proprietary, were past their expected lives and not supported by their original manufacturer. They used servo drives from a number of vendors including GE and proprietary ones made for the different vendors. Both the controls and servo drives had old electrolytic capacitors that were over fifteen years old. Even though these capacitors were hermetically sealed, they were starting to dry out and break down. Other electrical problems encountered with these older machine tools were the wiring harnesses that were fatigued and breaking. The wires were in the flexible conduit that allows the different axis's to move and were prone to fatigue failures that resulted in open circuits.

On the mechanical side, seals were dried out and leaked, way covers had leaked or were damaged, bearings and some lead screws were worn. Basically, KCP was running machine tools that could still make products but were unreliable and prone to breakdown. In a number of cases they were not supported by their original manufacturers who had been bought out or had ceased operation. The main components of the machine tools were still good but the electronics and mechanical wear items were near the end of their lives.

Previously, KCP had hired the original vendor to come in and evaluate their machine and quote on an overhaul. After agreeing on a cost, they would come in and upgrade their machine. They would install their proprietary control and servo drives, resulting in a machine tool that performed to the original specification.

In 2003, the American Hustler Lathe in the Process and Machining Evaluation Laboratory had the first OA Control installed. MTC was hired to upgrade this machine tool. Main components included an off-the-shelf Pentium PC, NT operating system, touch screen monitor, relay tree, new off-the-shelf servo drives, resolvers, solenoid switches and new wiring harness. MDSI's Open CNC control software was installed to act as the machine tool interface and command structure. This revitalized the machine tool. KCP discovered during the setup that the $\mathrm{Z}$ axis lead screw had been stretched and had a 0.002 error over the length 
of it travel. By using maintenance's laser interferometer system, KCP was able to reduce the error to under 0.0003 over the same travel.

Before this project, a second contract was issued with another outside vendor and both American Lathes were upgraded in the Model Shop. Maintenance engineering was unhappy with both previous vendors because they failed to provide adequate documentation. It was decided that KCP would work with the next vendor so that KCP could learn to upgrade the machine tools themselves.

KCP worked closely with Agile when they upgraded the Hardinge CHNC and CNNC4 lathes during their upgrades and with MDSI when the White Sundstrand was upgraded (5 Axis Machining Center). KCP started to do their own upgrades and have trained their electricians and machine repairmen to do the upgrade installations. They have upgraded the operating system from NT to Windows 2000 Professional to be compatible with KCP's networks. KCP has upgraded the versions of Open CNC to newer versions of MDSI software as they have become available, so that all the machine tools are using the same versions of software. They have acquired more accurate resolvers and newer solid state servo drives. The maintenance department has only one CNC control to learn for the upgraded machine tools. KCP has added mist collectors, probes capability, auxiliary spindles and been able to control their operation with these controls. These old machine tools are now more accurate, reliable and easier to repair than the original machine tool when they were new. KCP can now obtain generic off-the-shelf components for repair. They have expanded the machine tools capabilities and increased their accuracy

In 2006, the author presented to the Subprogram Manager for NNR \& ADAPT the following slides that show the progress made on the installation of OA Controls \& Machine Tool Upgrades project, which is part of the Agile Machining \& Inspection NNR project. In 2007, FM\&T completed the last machine tool which was the K\&T Moduline 5 Axis Machining Center. 

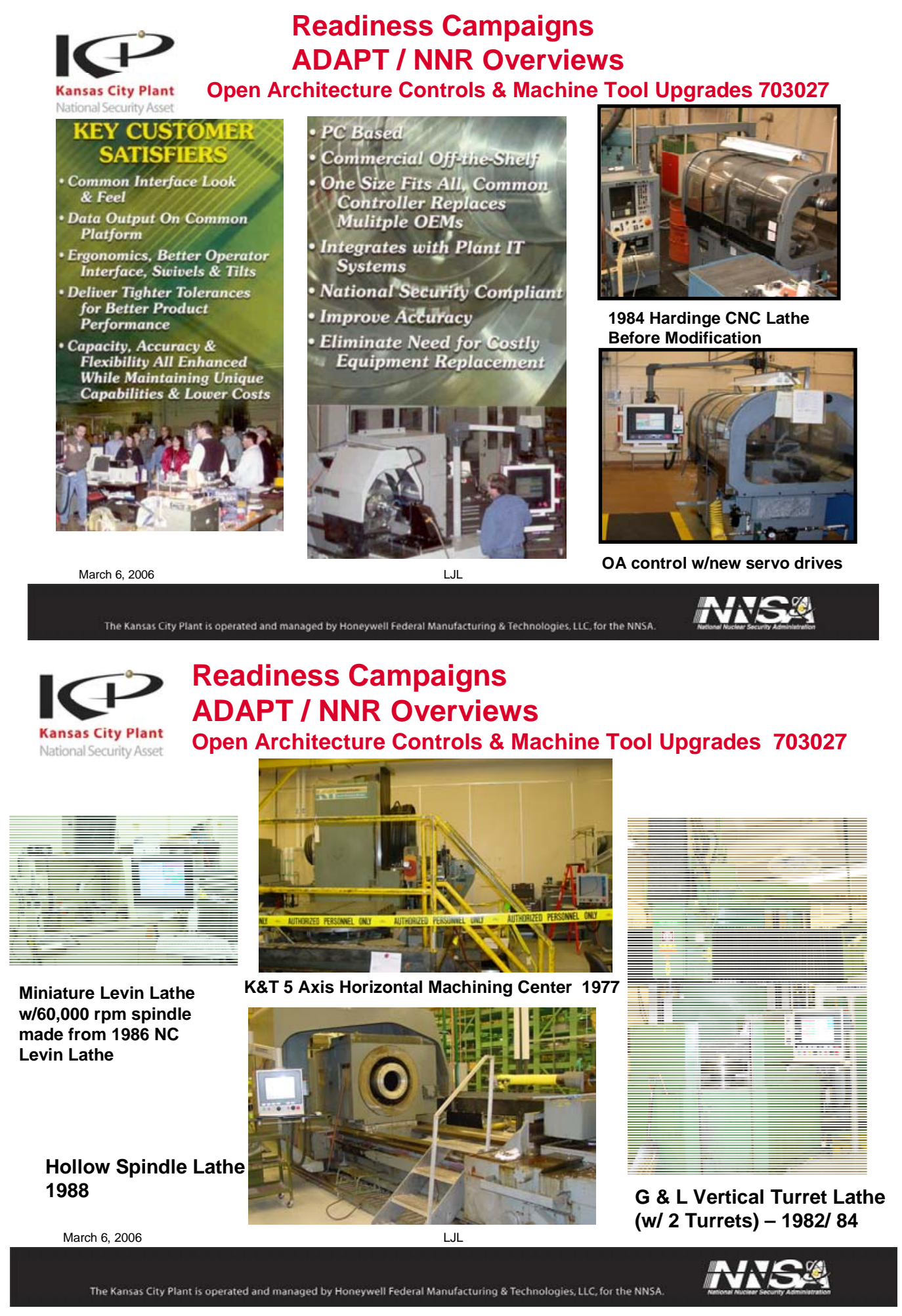


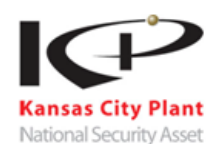

\section{Readiness Campaigns \\ ADAPT / NNR Overviews \\ Agile Machining \& Inspection}

- Install OA Controls on all Bostomatic Machining Centers

- OA Controls have proven extremely successful

- Machine tools can be adapted with new technologies at minimum costs

- High Velocity Spindle in

- On Machine Probing in

- Installation of Mist Collector in

- Easy of electrical installation \& maintenance

- Reduced number of machine tool controls

- Increased accuracy of machine movement with tighter compensation intervals

- Requested to modify machine tool at LANL

- Support of both Senior Leadership \& KC Area Office

Figure 10. Readiness Campaigns Slide Presentation

The following machine tools have been modernized:

American Hustler Lathe - Department D PMEL

Large American Lathes (2) - Department C

Hardinge CHNC (5) - Department B, Department E

Hardinge CHNC4 (2) - Department B, Department D

Bostomatic Machining Center - Department C

White-Sundstrand 5 Axis Machining Center - Department B

American Lathes (3) - Department B, Department F (1)

Bullard Lathe - Department F now in Department C

Hollow Spindle - Department B

Levin CNC Miniature Lathe - Department C

T- Bed Lathes (3) - Department C Model Shop \& Tool Room

Moduline 5 Axis Machining Center Department B

Twenty-three machine tools have been modernized. Six were modernized previous to this project. Seventeen have been completed under this project. A number of these machine tools were selected for the transformation as part of KCRIMS. At present, 16 have been designated to make the move and are in the floor plan. Two of the machine tools not going are part of the heavy machining capability that is not being transitioned to the new facility and four because of excess capacity and down sizing.

Recently in "Connections," a publication of FM\&T Communications, the following article on the modification of 45 Reentry Vehicles for the Department of Defense was published. The machine tool in the background is the modernized 5 Axis Moduline Machining Center. During this program, no machine problems were encountered because of the upgrades. All these machine tools have contributed to the mission of FM\&T. They have taken old, unreliable machine tools and made them consistent machines with the same basis PC control with high reliability, better accuracy and more easily repaired by maintenance staff with off- 
the-shelf generic components. In addition, in the future, as new more accurate resolvers, lower power servo drives become available KCP will be able to upgrade these machine tools themselves.
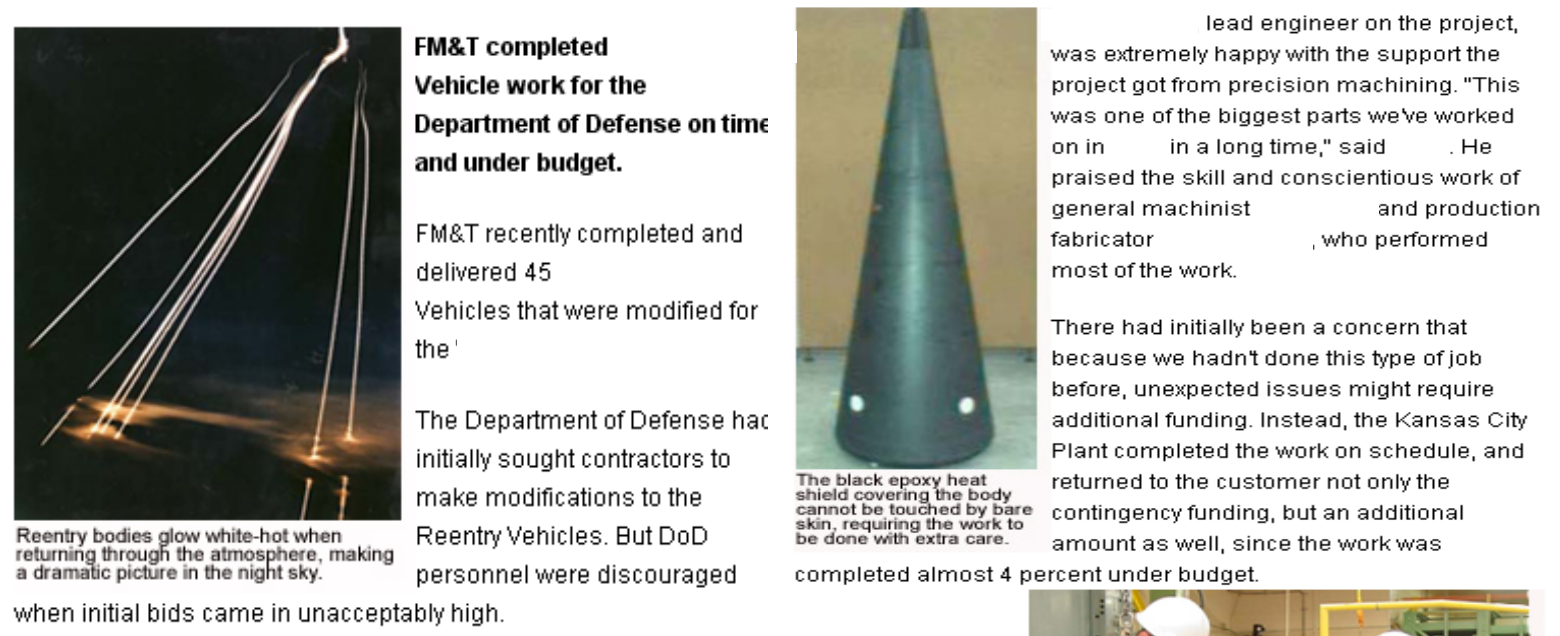

FM\&T, which did not originally bid on the work, was recommended for the job because of our well known reputation for high quality machining. In a rebid for the work, FM\&T won the contract.

began processing the first parts in January and continued to produce about eight units a month until the job was done.

The units required careful handling because the epoxy heat shield (the black material on the outside) cannot be touched by bare skin. Special fixturing was required to hold the units, and orange neoprene covers were used to protect the finish during much of the work

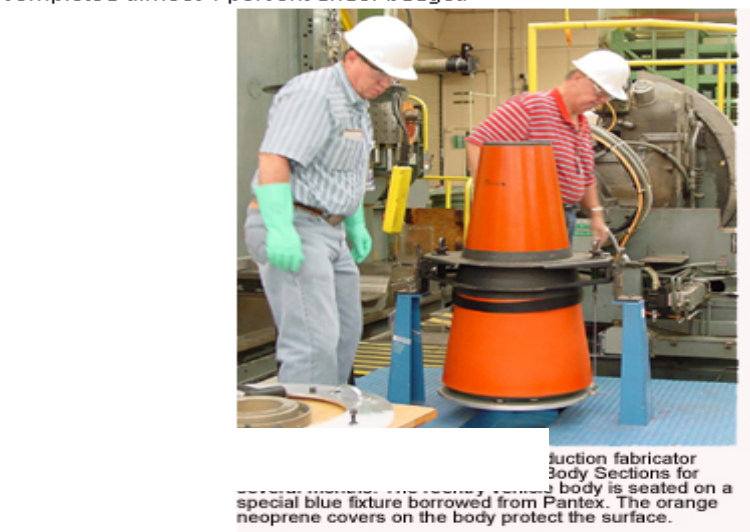

Figure 11. Article from "Connections" - K\&T Machining Center w/OA Control in Background

\section{0 - DNC/CRONOS Deployment - L2 Milestone}

All machine tools listed in Table 1 are connected to the CRONOS network where classified NC programs can be pushed from classified work stations connected to CRONOS to machine tool's CNC control for part fabrication. This eliminates the need to generate CREM to move the classified program from the classified work station to the classified machine tool controller.

In FY08, the fiber network was installed in the Model Shop and Tool Room (Department G) previously Department B, Department F and Department E machine tools listed in Table 1 were connected to the network. Interface equipment was installed within the machine tool control cabinet and connected to the new CRONOS network. All the machine tools listed in Table 1 will either be moved to the new facility, be used for dual build capability while moving in the present facility, or to meet the NNSA goal of removing CREM from the current facility.

Under the KCRIMS plan the equipment from Department C, 17 (unclassified machinist training area) and Department B (both the classified and unclassified room) will be combined 
into one department, SAM. Department E portions of Department H (Welding) and Department I will be combined together as the Gas Transfer Systems (GTS). Both GTS and SAM will be within the secure portion of the new facility where all the machine tools will be capable of running classified product and where the CRONOS network will be available. Therefore, there will be no need for CREM to transfer classified programs from the servers to the machine tool controllers.

\begin{tabular}{|c|c|c|c|c|}
\hline $\begin{array}{l}\text { Mach } \\
\text { CE \# }\end{array}$ & $\begin{array}{c}\text { Comp } \\
\text { CSI\# }\end{array}$ & $\begin{array}{l}\text { Cronos DNC } \\
\text { Machine Tools }\end{array}$ & Dept & Control \\
\hline 22324 & 30254 & Ex-Cell-O Lathe & $\mathrm{C} / \mathrm{MS}$ & OA \\
\hline 35368 & 18061 & American Lathe & $\mathrm{C} / \mathrm{MS}$ & OA \\
\hline 53482 & 8901 & Pnuemo Lathe & $\mathrm{C} / \mathrm{CR}$ & $\mathrm{OA}$ \\
\hline 55934 & 18062 & American Lathe & $\mathrm{C} / \mathrm{MS}$ & OA \\
\hline 56009 & 24438 & Okuma Lathe & C/MS & Prep \\
\hline 60543 & 19886 & Bullard Lathe & $\mathrm{C} / \mathrm{MS}$ & $\mathrm{OA}$ \\
\hline 66374 & 24373 & Hurco 50 Mill & $\mathrm{C} / \mathrm{TR}$ & Prep \\
\hline 74580 & 24369 & Hurco 20 Mill & $\mathrm{C} / \mathrm{TR}$ & Prep \\
\hline 80512 & 20051 & Levin Lathe & $\mathrm{C} / \mathrm{MS}$ & $\mathrm{OA}$ \\
\hline 81386 & & Stereo Lith & C/MS & $\mathrm{OA}$ \\
\hline 83837 & 24428 & Hurco 20 Mill & $\mathrm{C} / \mathrm{MS}$ & Prep \\
\hline 83839 & 24427 & Hurco 20 Mill & $\mathrm{C} / \mathrm{MS}$ & Prep \\
\hline 83861 & 24380 & Hurco 20 Mill & $\mathrm{C} / \mathrm{TR}$ & Prep \\
\hline 84653 & 24430 & Charmiles EDM & $\mathrm{C} / \mathrm{MS}$ & Prep \\
\hline 113289 & 30205 & Moore Lathe & $\mathrm{C} / \mathrm{CR}$ & OA \\
\hline 113833 & 24437 & Hardinge Lathe & $\mathrm{C} / \mathrm{TR}$ & Prep \\
\hline 210030 & 24374 & Monarch Mill & $\mathrm{C} / \mathrm{CR}$ & Prep \\
\hline 210505 & 32305 & Bostomatic Mill & $\mathrm{C} / \mathrm{MS}$ & $\mathrm{OA}$ \\
\hline 210973 & 24436 & Toyoda Mill & $\mathrm{C} / \mathrm{MS}$ & Prep \\
\hline 211804 & 24435 & Mori Seiki Mill & $\mathrm{C} / \mathrm{MS}$ & Prep \\
\hline 212260 & 24372 & Charmiles EDM & $\mathrm{C} / \mathrm{CR}$ & Prep \\
\hline 212583 & 24368 & Hauser Grinder & $\mathrm{C} / \mathrm{CR}$ & Prep \\
\hline 213384 & 16548 & Mori-Seiki Lathe & $\mathrm{C} / \mathrm{MS}$ & $\mathrm{OA}$ \\
\hline 81232 & 24533 & Mori Seiki Lathe & $E$ & Prep \\
\hline 81233 & 24531 & Mori Seiki Lathe & $E$ & Prep \\
\hline 84148 & 24525 & Index Lathe & $E$ & Prep \\
\hline 84697 & 24529 & Index Lathe & $E$ & Prep \\
\hline 113708 & 24520 & Hardinge Lathe & $E$ & Prep \\
\hline 113709 & 24518 & Hardinge Lathe & $E$ & Prep \\
\hline 113710 & 24522 & Hardinge Lathe & $E$ & Prep \\
\hline 113711 & 24526 & Hardinge Lathe & $E$ & Prep \\
\hline 113712 & 24524 & Hardinge Lathe & $E$ & Prep \\
\hline 113713 & 24527 & Hardinge Lathe & $\mathrm{E}$ & Prep \\
\hline 210158 & 24530 & Hardinge Lathe & $E$ & Prep \\
\hline 210278 & 24523 & Mitsui Seiki Mill & $E$ & Prep \\
\hline 210279 & 24519 & Mitsui Seiki Mill & $E$ & Prep \\
\hline 210284 & 24521 & Monarch VMC & $E$ & Prep \\
\hline
\end{tabular}




\begin{tabular}{|c|c|c|c|c|}
\hline 210525 & 24528 & Hardinge Lathe & $E$ & Prep \\
\hline 210909 & 24534 & Mori Seiki Mill & $E$ & Prep \\
\hline 212002 & 19981 & Hardinge Quest & $E$ & $\mathrm{OA}$ \\
\hline 212660 & 24516 & DIXI 5X Mill & $E$ & Prep \\
\hline 213446 & 24532 & Mori Seiki Lathe & $E$ & Prep \\
\hline 56734 & 19492 & American & $\mathrm{F}$ & $\mathrm{OA}$ \\
\hline 66415 & 24367 & Monarch/Alpha & $\mathrm{F}$ & Prep \\
\hline 210400 & 24366 & Lumonics Laser & $\mathrm{F}$ & Prep \\
\hline 210910 & 24365 & Monarch Mill & $\mathrm{F}$ & Prep \\
\hline 212009 & 24382 & Mori Seiki Lathe & $\mathrm{F}$ & Prep \\
\hline 212010 & 24383 & Mori Seiki Lathe & $\mathrm{F}$ & Prep \\
\hline 212661 & 32775 & Hermle Mill & $\mathrm{F}$ & $\mathrm{OA}$ \\
\hline 214347 & & Hermle Mill & $\mathrm{F}$ & $\mathrm{OA}$ \\
\hline 35393 & 19803 & G\&L 5X Mill & $\mathrm{B}$ & $\mathrm{OA}$ \\
\hline 50744 & 19686 & American Lathe & $\mathrm{B}$ & $\mathrm{OA}$ \\
\hline 51427 & 15159 & American Lathe & $B$ & OA \\
\hline 53480 & 31936 & American Lathe & $\mathrm{B}$ & $\mathrm{OA}$ \\
\hline 55674 & 19493 & G\&L VTL Lathe & $B$ & $\mathrm{OA}$ \\
\hline 63977 & 24375 & K\&T High Speed & $\mathrm{B}$ & Prep \\
\hline 84774 & 24377 & Monarch Mill & $\mathrm{B}$ & Prep \\
\hline 113622 & 24378 & Monarch Mill & $\mathrm{B}$ & Prep \\
\hline 113623 & 24379 & Monarch Mill & $\mathrm{B}$ & Prep \\
\hline 113801 & 24370 & Bostomatic Mill & $B$ & Prep \\
\hline 210185 & 24376 & Monarch Mill & $\mathrm{B}$ & Prep \\
\hline 210186 & 24381 & Monarch Mill & $B$ & Prep \\
\hline 210693 & 24535 & Mori Seiki Lathe & B & Prep \\
\hline 212179 & 32774 & Hermle Mill & $\mathrm{B}$ & $\mathrm{OA}$ \\
\hline 212180 & 32776 & Hermle Mill & $B$ & $\mathrm{OA}$ \\
\hline 212655 & 24364 & Star Screw & $\mathrm{B}$ & Prep \\
\hline 213844 & 24371 & Star Screw & $B$ & Prep \\
\hline 131313 & 22705 & T\&C Test & $\mathrm{J}$ & Prep \\
\hline Desk_Test & 41238 & Black Box & $\mathrm{J}$ & Prep \\
\hline 54522 & 19680 & Hardinge & $\mathrm{K}$ & $\mathrm{OA}$ \\
\hline 213281 & 22692 & Hermle Mill & $\mathrm{K}$ & Prep \\
\hline 213288 & 22839 & Gildemeister & $\mathrm{K}$ & Prep \\
\hline 67260 & 22648 & Klingenberg & $\mathrm{L}$ & Prep \\
\hline 67969 & 22649 & OGP & $\mathrm{L}$ & Prep \\
\hline 212968 & 23797 & ESI Laser & $\mathrm{L}$ & $\mathrm{OA}$ \\
\hline 54096 & 18797 & Hardinge & $\mathrm{B}$ & $\mathrm{OA}$ \\
\hline 54097 & 18522 & Hardinge & $B$ & OA \\
\hline 54117 & 18799 & Hardinge & B & OA \\
\hline 54943 & 19889 & Hardinge & B & OA \\
\hline 55323 & 18798 & Hardinge & $B$ & $O A$ \\
\hline 56983 & 22703 & Star & B & Prep \\
\hline 58944 & 22701 & Star & $B$ & Prep \\
\hline 58998 & 22696 & Wasino Grinder & B & Prep \\
\hline 61394 & 22702 & Superslant & B & Prep \\
\hline 71907 & 22686 & Traub & B & Prep \\
\hline
\end{tabular}




\begin{tabular}{|c|c|l|c|c|}
113798 & 22698 & Boston Mill & B & Prep \\
\hline 113799 & 22708 & Boston Mill & B & Prep \\
\hline 212649 & 22840 & Gildemeister & B & Prep \\
\hline 1313 & 39004 & Test PC & J & OA \\
\hline
\end{tabular}

\begin{tabular}{l|l|l|l|} 
& \multicolumn{1}{|c|}{$\mid$} & \\
\hline K-Moved to new building & & \\
\hline K-T Move to new TOO Facility & & \\
\hline D- Dual Build & & \\
\hline N-R - Being replaced in FYOB currently hooked to CRONOS & & \\
\hline
\end{tabular}

Table 1, CRONOS Connections

A formal report KCP-613-8516, "DNC/CRONOS Deployment," outlining the work on this project has been submitted and includes the details of the project implementation.

\section{1 - OMGEC for OA/American Lathes}

On Machine Gauging and Error Compensation (OMGEC) 0 has been used at KCP for several years on the Hardinge Quest machine located in Department E. The advantage of OMGEC over commercial probing software, such as Renishaw, is a contoured surface can be measured, where commercial software can only measure in " $\mathrm{X}$ ” \& “Z” direction.

A retired engineer from Los Alamos, NM had written OMGEC while employed at LANL, then after retirement he started MecSoft, LLC. A purchase order was placed with MecSoft, LLC to develop, install and train using the OMGEC probing software on the American Lathes that had been upgraded with OA Controls. This software needed to be adapted to MDSI control software in order to use the same PC being used to operate the machine tool. This was different than previous OMGEC that required a second PC to communicate with the Fanuc control.

Software, probes and connecting hardware were installed on both American Lathes in Department C, three American Lathes in Department B and the American Lathe in Department F. All of these lathes are slated to make the transformation to the new facility under KCRIMS. The engineer wrote the computer code to interface OMGEC with the modernized American Lathes and installed the first system and verified its operation.

\section{2 - 3D-Micro Scale Implementation}

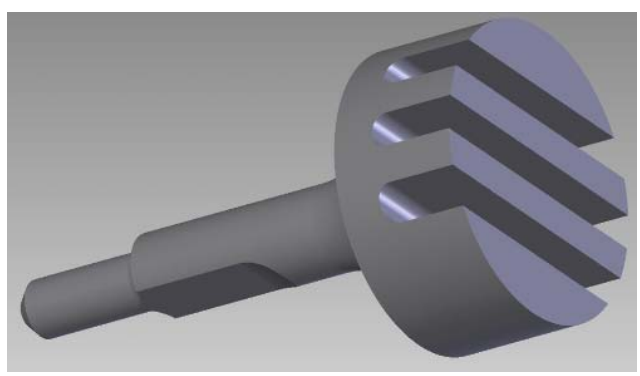

Figure 12. Sample Micro Part 
KCP supported micro-machined features to prepare for future work by machining 3D features on a very small scale using existing equipment. The machines evaluated were the Charmiles Wire EDM and the Levin Lathe. Features turned on the Levin Lathe were in the 0.005 ” Diameter range and the Wire EDM features were 0.0025 ”-0.0150” size range.

Based upon inspection data for the parts, the team learned about feature tolerancing, fixturing, and material selection for the miniature scale. This work supports development and production of future designs by providing manufacturability experience of miniature features. Additionally, several attempts were made to purchase parts from vendors throughout the country. However, as the micromachining field is still in its infancy, the technology was not found to be readily available from suppliers.

A formal report, KCP 613-8521, “3D Micro-Scale Machining Implementation,” has been submitted that details the activities of this project.

\section{$\underline{706685}$ - CMM Technology}

A comprehensive review and comparison was performed on CMM measurement results for the component that were inspected at IDC, a KCP supplier, and at KCP. There were two serial numbers inspected at each site, and 121 discrete measurements were performed for each serial number. FM\&T product and quality engineers, a design agency engineer, and inspection personnel from IDC subsequently met to discuss the results. Significant differences were highlighted to aid FM\&T’s engineers in evaluating the measurements. The vendor initiated actions on ten different items to improve the inspection and quality of the housings.

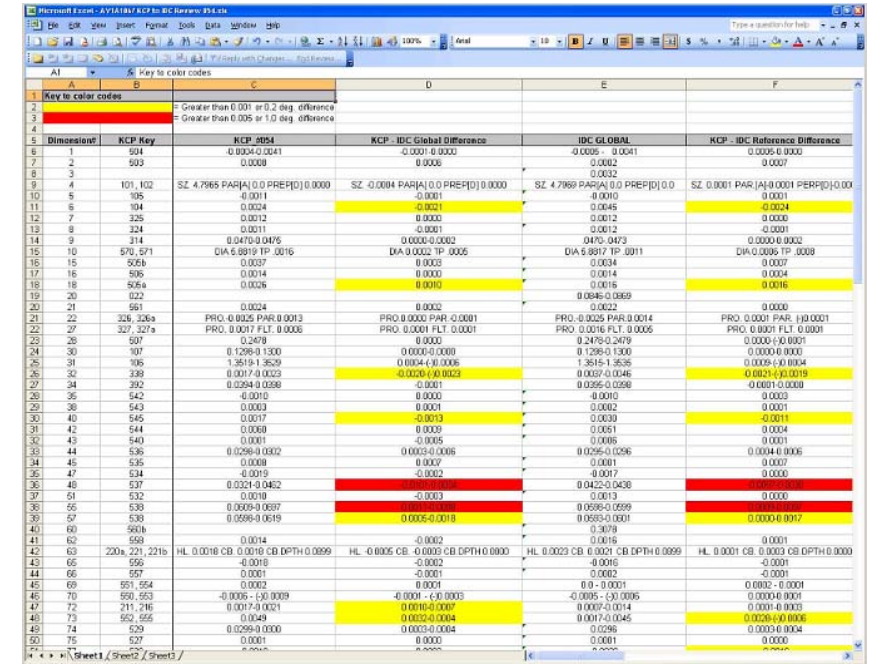

Figure 13. OSV Comparison Study

FM\&T personnel successfully ran a CMM inspection program created by FM\&T's FBMeas software and edited by personnel in the U.K.'s Atomic Weapons Establishment (AWE) to run on one of their CMMs. The CMM was running PC-DMIS, CMM inspection software used by AWE and by KCP. The program was run at KCP using an off-line version of PC-DMIS. Results of the inspection run were furnished in .pdf, .rtf, and Microsoft Excel formats, 
enabling AWE and KCP to investigate different output formats. FM\&T personnel also reviewed and improved tolerancing schemes on two different AWE stronglink parts to assist in knowledge sharing between the two industrial partners.

Below are just two of the examples of reports that were created from CMM data tables automatically. These reports can be used by engineering, quality, purchased product engineering in final form to be included in product files. Product scorecards and CMM inspection summaries were provided for 1662 different part number runs so far this fiscal year. Approximately $\$ 156.7 \mathrm{~K}$ was saved this fiscal year by automatically generating these reports.
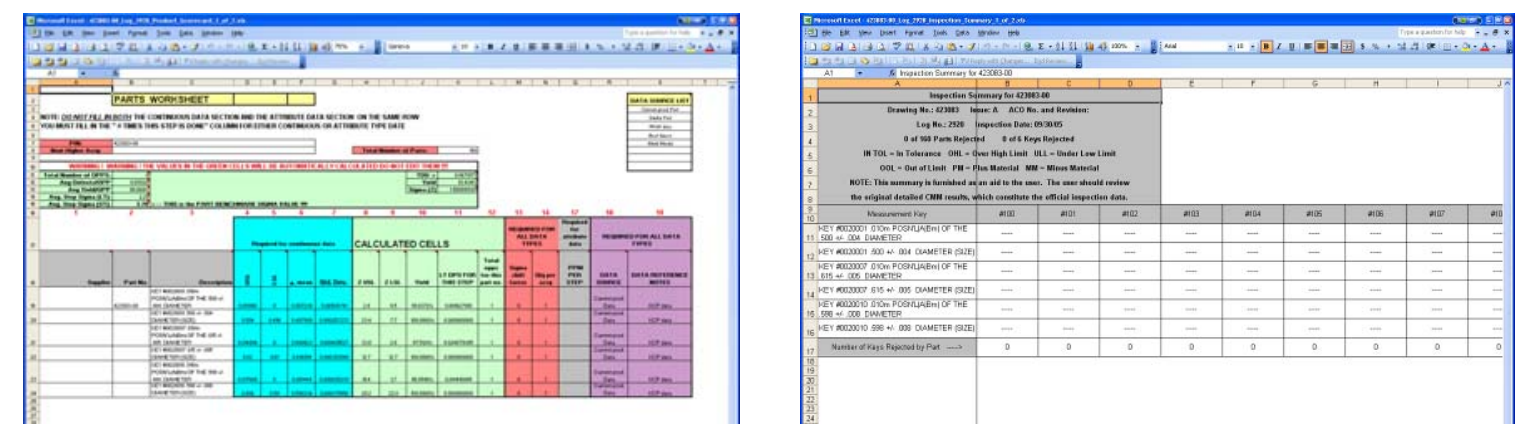

Figure14. Automatically Generated Product Score Card and Inspection Summaries

The PC-DMIS standard report template was revised to include classification markings at the top and bottom of each page of printed measurement results. This improvement will eliminate the need for engineering, production and inspection personnel to hand-stamp these results.

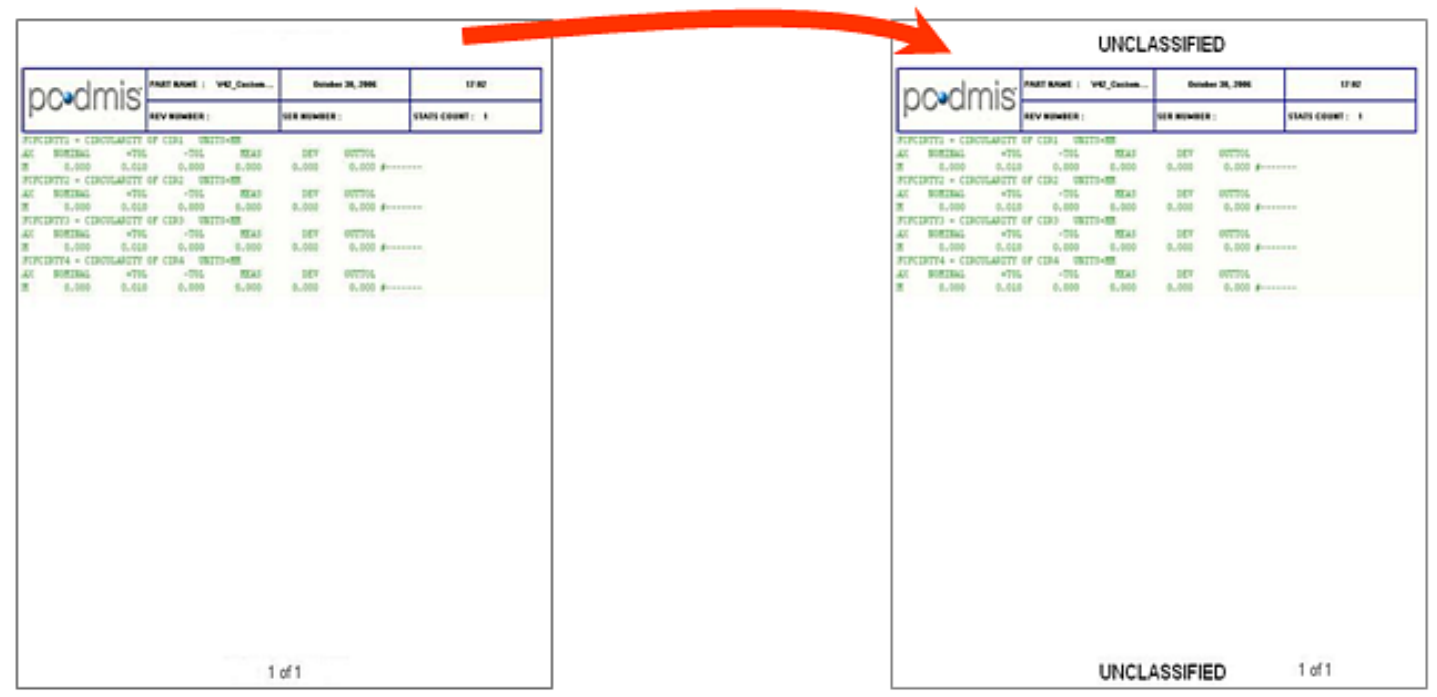

Figure 15. Classification Markings Added to Headers and Footers

A formal report KCP-613-8518, "CMM Technology,” has been submitted that outlines all the activities that have been accomplished on this project. 


\section{4 - Agile Inspection}

Logbooks were established in the inspection department to track orders. A logbook is filled out when the order is received, when the order leaves the department, and when the order is placed on the NCR shelf. This allows the Quality Team Manager (QTM) to be able to track an order and to know easily where the order is and which inspector is working on it. A new contour reader was obtained and a program was written to help usability of the contour reader. Cross training of the majority of the inspectors in the department was completed to allow flexibility and increase efficiency. Inspector needs were reviewed and a basic set of tools needed were identified. This "Tool Kit" will be given to each inspector to increase efficiency in the department. As part of this review, a list of equipment needed in the department (not necessarily with each inspector) was also identified and is being purchased.

A formal report has been generated that outlines the activities on this project.

\section{Conclusions}

This project has been agile in meeting the objectives of its business plan while everything it was based on was being changed. KCP is better prepared for the consolidation of the machining departments in KCRIMS and now have new operating methods.

It has upgraded the machining departments by converting older machine tools with aging computer systems into modern reliable machine tools with better accuracy and dependability. Since the maintenance department was trained and made the conversions they are better prepared to trouble shoot and repair these machine tools when necessary. KCP has expanded the capabilities of these machine tools by adding probing. KCP has saved millions of dollars in replacement costs and now have lathes and machining centers using the same computer numerical control that can be upgraded by staff as new versions of operating systems PC Operating Systems, MSDI Open CNC become available. KCP now has a choice and can purchase generic replacement hardware for the computers, relay trees, resolvers and servo drives and not pay the premium from the machine tool manufacturers for their proprietary components.

KCP has implemented new inspection methods and had them approved by the design laboratories to accept WR product. KCP has set up new operating procedures in inspection areas. In the case of the VOC, KCP has applied for a patent.

KCP has improved the plant security with the elimination of CREM. KCP now transfers classified NC programs from the computer work stations to the CNC controls by using the CRONOS network in four machining departments (Department C, E, F and B) and not using CREM.

KCP now automatically load CMM data from equipment to bomb books and product scorecards instead of doing it manually. KCP is expanding this program to the OSV CMM data. 
Finally, KCP has reviewed how they operate in specific machine tool cells and implemented new methods for operation. The Hermle milling sell was the focus of a black belt project and the Mill Turn cell was the focus of a lean project. These examples will be expanded as KCP consolidates the machining departments.

Through the years a number of cost savings and productivity events have been submitted related to these projects. KCP will continue to implement these new procedures in the future to reduce operating costs and reduce cycle times. 